\title{
Towards an investigation of information literacy in South African students ${ }^{1}$
}

\author{
Y. Sayed \\ Faculty of Education, University of the Western Cape, Private Bag X17, Bellville, 7535 Republic of South Africa \\ K. de Jager* \\ School of Librarianship, University of Cape Town, Private Bag, Rondebosch, 7700 Republic of South Africa \\ kdej@education.uct.ac.za
}

\begin{abstract}
To launch a major research project into the state of information literacy at the five institutions of tertiary education in the western Cape, the INFOLIT project of the Cape Library Co-operative (CALICO) appointed a Research Team to conduct the investigation. The first part of the investigation consisted of an attempt to obtain an operational definition of the concept 'information literacy'. This article presents an overview of key trends emanating from a review of the recent literature on information literacy, and discusses the results obtained by a series of focussed group interviews on the purpose and meaning of the concept. An operational definition of information literacy, appropriate to the South African tertiary education environment, is proposed
\end{abstract}

Die INFOLIT-projek van CALICO (Cape Library Co-operative) het onlangs 'n navorsingspan aangestel om inligting in te win oor die stand van inligtingsgeletterdheid aan die vyf inrigtings vir tersiêre onderrig in the Wes-Kaap. Die eerste gedeelte van die ondersoek was 'n poging om 'n operasionele definisie daar te stel vir die begrip 'inligtingsgeletterdheid'. Hierdie artikel bied ' $n$ blik op die belangrikste tendense wat spruit uit ' $n$ oorsig oor die onlangse literatuur, en bespreek die resultate van 'n reeks fokusgroeponderhoude oor die doel en sin van die begrip 'inligtingsgeletterheid'. 'n Operasionele definisie, wat van toepassing is op Suid-Afrikaanse tersiêre onderrig, word voorgestel.

*Author to whom correspondence should be addressed.

'Knowledge is of two kinds: we know a subject ourselves, or we know where we can find information upon it' (Samuel Johnson, 1791).

A consortium of the five tertiary education institution libraries in the Western Cape, the Cape Library Co-operative (CALICO), during 1995 received a generous donation from the Reader's Digest Foundation towards enhancing teaching and learning through promoting information literacy across the campuses of the three universities and two technikons in the western Cape. This project became known as INFOLIT, and established as a basic requirement, a major research investigation into both the state of information literacy at the five tertiary institutions and into the need for appropriate interventions which would enhance levels of information literacy in all the students on the CALICO campuses and eventually the schools in the region.

It was agreed that a key step in the research process would be to arrive at a mutually agreed and understood definition of information literacy, which would be recognized and owned by both staff and students at the different institutions. For this reason, it was decided to conduct a series of focus group interviews with key strategic informants who have both experience and understanding of the field of information literacy, in order to achieve such a definition. Ultimately, the aim was to generate a common understanding and definition of information literacy on which to base and develop the research instruments. At the same time, a survey of key recent literature was launched.

The literature on information literacy, particularly with a focus on tertiary education, has recently been particularly evident (see Rader, 1994). This increase in literature attests to the changing nature of information in our society and the move towards the information society. Information literacy has thus become a growing field of academic enquiry and research. In this article the literature published during the period 1993-1995 will be reviewed. This complements an extensive survey completed by Behrens (1992) for her doctoral thesis. However, the present article does not presume to review exhaustively all articles published during this period. Instead, key texts which signify general trends and highlight important issues related to the notion of information literacy, are identified and discussed. The main purpose of this survey was to gain an overview of the central areas of agreement regarding the definition of information literacy with a view to generating a South African contextual application of the concept.

This article is a report of the results, which produced an operational definition of information literacy in the South African context, and on which the development of appropriate research instruments will now be based. It is recognized that information literacy does not pertain exclusively to tertiary education, but that the initial focus of the project is on the tertiary education sector.

\section{Reviewing the definitions}

The notion of information literacy emerged in the 1970 s spurred on by, inter alia, the advent of new information technologies and consequently signalled the need for libraries and librarians to redefine their roles in this context. The definitions of information literacy proposed in the literature reviewed, can be situated on a continuum ranging from those which are narrow and specific to the more global and 
encompassing ones. Narrow and specific definitions emphasize mainly skills necessary to handle new forms of information technology and conceive of information literacy as mastery and understanding of technologies that transmit and offer information. An example of this approach would be definitions which mainly or solely focus on narrow skilling, inter alia on computer literacy, which is perceived to be necessary for handling new forms of information technology. Global definitions emphasize access to sources of information, skills to locate information and critical evaluation of information. The following lengthy exposition of the abilities to be acquired by the information literate by Bruce (1995:163), provides a representative example of such definitions:

- understanding the nature of the information society

- acquiring values that promote information access and use

- being able to implement the processes of identifying an information need

- locating, retrieving, evaluating and synthesizing the information required

- developing a high level of communication skills, including the ability to communicate with colleagues and information professionals

- developing a sound knowledge of information sources, including network sources, and strategies for using them

- developing the ability to manage the information retrieved through the appropriate use of, for example, word processors, and bibliographic management software

- developing a familiarity with the hardware of information technology, books, newspapers, videos, compact discs computers and all their accompanying apparatus.

Using the above global definition, the various sub-concepts that cluster around the concept of information literacy, will be analysed.

\section{Information literacy and basic literacy}

Most definitions of information literacy suggest that it is a literacy akin to reading and writing. Thus, just as much as people are able to read and write, they should also be able to master the skills of managing and using information generated through new information technologies. Information literacy is therefore part of other literacies and for some, parasitic on others such as reading and writing. This idea is clearly expressed by Makhubela and Koen (1995:14), who state that ' ... information literacy contributes to a higher level of literacy!' Thus, information literacy presupposes the possession of basic reading, writing and numeracy skills and contributes and advances on these literacies in the information age. In the South African tertiary context, however, the acquisition of this skill must go hand in hand with mastering academic literacy.

\section{Information literacy and location skills}

All definitions of information literacy emphasize the fact for people to be information literate, they should be able to locate the sources of information. This requires the skills of knowing how to access various information technologies and includes such skills as the ability to utilize a library, a computer and the Internet. These skills require a high degree of exposure to, and familiarity with, the various sources of information. McClure (1994) refers to these skills as network literacy, traditional literacy, media literacy and computer literacy. Thus, location skills refer to the ensemble of abilities that allows an individual to identify and find sources of information, which is only possible if one has the requisite skills.

\section{Information literacy and critical thinking skills}

The ability to access and manipulate information from various sources is a necessary but not sufficient condition for definitions of information literacy. All definitions argue that the notion of information literacy implies that once the information is sourced, an individual should be able to both critically evaluate and deploy such information to solve a particular problem or task. Some definitions go as far as to suggest (McClure, 1994, for example) that all information literacy activities are directed towards solving problems. This definition is too limiting, since all instances of information searching are not solely directed towards an immediate problem. Information searching may be motivated by other goals such as a desire to learn, which is not simply reducible to instrumental educational goals. However, what it emphasized, is the fact that central to successful information literacy programmes is the generation of critical skills which allow the individual to critically reflect on the information obtained and to consequently effectively deploy the information to generate new ideas or knowledge. Lennox and Walker (1993:315) sum this up as follows:

\section{'... inherent in the definition of information literacy is the ability to dissect and understand what is seen and heard (and read - authors' insertion). If we are to teach information literacy, we must teach students to question, sort, discriminate, select, and analyze the array of messages that are presented in traditional or electronic formats, and then to reassemble the parts into new and meaningful wholes'.}

This call is emphasized in the paper by Makhubela and Koen (1995), where they reiterate the need in historically disadvantaged institutions in South Africa to teach students not just how to use the library but also how to analyse critically and to evaluate information they obtain.

Information literacy and changing perspectives on teaching and learning: a new learner-centred, lifelong learning paradigm?

The generation of critical cognitive skills which is central to definitions of literacy implies, for many writers, a change in the way the teaching/learning dynamic is conceived. Whereas traditional notions of teaching and learning have been lecturer-led and textbook-centred, the impact of new 
information technologies requires that learning is conceived not as transmission of information but rather as the generation of critical skills in learners to search for, evaluate and use information. This implies that learning should be learnercentred with the focus on guiding and directing learners to ways of solving problems or acquiring understanding rather than prescribing or limiting students to single sources of information. Teaching and learning thus cannot be left to transmitting information since this is virtually unlimited, nor can it be solely dependent upon the instructor, since there are multiple sources of information. If this is true, then information literacy, according to various writers, should be directed towards showing people how and why rather than what. By empowering learners to be self-directed and independent, it is argued that this allows them to engage in learning beyond the confines of the formal instructional setting. Providing learners with the skills to engage in lifelong learning, allows them to respond to information throughout their lives and enable them to be active citizens.

Bruce (1995:165) captures this shift in the following way:

'... strategies such as contract, resource-based, and problem-based learning are more suitable than traditional lecture and tutorial based courses. Courses falling into the latter category need to focus on using assignments, or other elements that encourage independent learning, to foster information literacy'.

The above definition aptly synthesizes what many (e.g. Ford, 1994; Rader, 1995) argue to be the key educational challenge of the 21 st century, namely, the need to move from content to process and the need to equip students with skills to use information independently, rather than to rely on the teacher/ lecturer. Information literacy is thus central to the restructuring of educational thought and policies (Adams \& Bailey, 1993), and an important factor in enhancing the quality of life of the learner (Marais, 1994:14).

Enabling students to become independent learners implies that they are prepared and equipped to learn throughout their lives. This notion of lifelong learning is distinct from that articulated in the South African context which emphasizes access to learning for all and underscores learning as that which occurs in many contexts and not only that of the school and the university. However, it shares with the South African definition the need for a more comprehensive and visionary concept which includes formal, non-formal and informal learning extended throughout the life span of an individual to attain the fullest possible development in personal, social and professional life (National Education Policy Investigation, 1993:8).

\section{Information literacy and knowledge}

Many of the definitions of the notion of information literacy do not often make a distinction between the concepts of information and knowledge. Often these two concepts are either used interchangeably or the notion of information subsumes that of knowledge. Many definitions assume that learners who are able to critically evaluate and use information are able to generate knowledge. Whilst this is true, it is analytically useful to make the distinction between information and knowledge. Information is inert and passive, whereas knowledge generation is a creative process requiring active engagement and critical thinking skills. This distinction underscores the point that mastery of information literacy skills is an integrated part of an active, learner-engaged process of generating knowledge in the context of tertiary education.

\section{Normative orientations in the definitions}

A key characteristic of most, if not all, definitions of information literacy is that they are normatively orientated (this begs the obvious question of whether any definition can be absent from a normative orientation). Information literacy is presumed to be directed towards for example, the creation of independent learners or non-transmission modes of teaching. Two key normative orientations are prominent. Firstly, information literacy should generate civic-minded and knowledgeable citizens who are able to access and utilize information to enhance their civil participation. This idea is captured in the following quotation:

'... information literacy is and will be essential to a citizenry to prepare to participate in the political decision making that affects their lives' (Lennox \& Walker, 1993:316).

Secondly, information literacy is central to economic development and growth both of the individual and the company (or country). Thus, the acquisition of information literacy is particularly vital in ensuring economic empowerment for individual and economic prosperity for a nation. This is best expressed by the following quotation:

'Information literacy ... is an awareness of the growing role of the technological enablers that allow a company to re-engineer the entire business process. ... information literacy involves an understanding that competitive business performance is based on an appreciation of the critical nature of information whether it be computer based or not' (Kanter, 1995:7).

\section{Factors absent in the definitions}

The definitions of information literacy reviewed above, highlight the key concerns of the information literacy movement. In particular, they emphasize the need to move away from narrow bibliographic instruction programmes and from a perception that information skills training is in the domain of librarians. Instead, it signals that a more holistic approach to education in which librarians, academics and others collaborate in generating cross-curricular programmes.

However, the definitions of information literacy reviewed above do not always pay sufficient attention to certain issues which are crucial in developing a fuller understanding of the concept in the South Africa context. These are: 


\section{Attention to context}

Most definitions of information literacy ignore the context in which learning and teaching takes place. These factors include, inter alia, the histories and tradition of institutions, departments and faculties, infrastructure and resource issues and the disciplinary orientations and frameworks within which teaching and learning takes place. Information literacy is therefore as much about the resources and materials that frame the nature and form of information as it is about higher order cognitive skills.

\section{Information literacy and access}

Many definitions of information literacy underplay the fact that central to the successful implementation of information literacy programmes and to the acquisition of such skills, is access to the relevant information technologies. This is not always the case for all learners, particularly in the South African tertiary sector where historically-disadvantaged institutions have been denied and deprived of the necessary resources which facilitate connection and supply access to various information technologies. For example, most historically disadvantaged institutions have poor library holdings and computer facilities, making information access difficult. Notions of information literacy from the developed world, often take for granted basic facilities and resources which simply do not exist in South Africa. Successful information literacy tuition, as Makhubela and Koen (1995: 18) note in their conclusion, is as much about the library resources and facilities at the University of the Western Cape, as it is about changing approaches to learning.

\section{Information literacy and prior learning}

Many definitions of information literacy do not take into account the learner's prior learning experiences. The definitions assume that all learners are homogeneous and that they are all equal when they enter tertiary institutions. Thus not many of the definitions refer to the experiences of learning that learners bring to bear as they access, evaluate and use information in the tertiary education context. In South Africa it is important to take cognisance of the effect of apartheid education on learners, particularly in designing programmes geared towards enhancing information literacy.

\section{Characteristics of an information literate person}

The definitions of information literacy reviewed above implicitly presume certain characteristics and qualities which an information literate person should possess. This skill is best expressed by Breivik in an earlier work:

'To accomplish this (lifelong learning), students need to become information literate, whereby they

- Understand processes for acquiring information, including systems for information identification and delivery.

- Can evaluate the effectiveness of various information channels ...
- Master basic skills in acquiring and storing their own information ...

- Are articulate, responsible citizens in considering public policy issues relating to information ...' (1987:46-47).

This articulates the ways in which an information-literate person is conceived in the various definitions of information literacy. The key characteristics are the ability of learners to access, evaluate and use information. However, as was pointed out in the previous section, these definitions omit consideration of factors such as contextually located learning (or what the academic development fraternity refers to as situated cognition) and students' prior learning experiences.

\section{Interviews with key informants}

As part of the process of arriving at an operational definition that would be recognized and owned by service providers and other role players on all the CALICO campuses, it was decided to consult with key informants from all five of the institutions, to arrive at a common understanding and definition of information literacy. The perceived advantage of these discussions was that they would provide a forum for people to develop a collective view of the subject at hand and to obtain as an end product an operational definition of information literacy. This definition could then be used to guide and inform the design of questionnaires and interviews for the Research Team's investigation into information literacy at the five CALICO institutions.

It was clear that representatives from all five institutions had to be interviewed and informants were selected from the libraries, from academic development programmes, from information technology services and also academics who had in the past expressed an interest in aspects of information literacy and/or who were considered to be knowledgeable in the field. Some 30 key informants were identified and 27 eventually attended one of the three focus group interviews.

Before the start of the focus group sessions, one pilot interview was held, consisting of a discussion of the draft interview schedule with an identified expert in the field of academic development. The discussion lasted for three quarters of an hour and provided a useful framework for the interviews that were to follow.

Three focus group interviews were held, each attended by between eight and ten interviewees. The interviews were held on three different campuses and representatives from at least two different institutions were present at each. No attempt was made to group the interviewees according to discipline or interest, as it was considered important to gain the opinions from as broad a cross section of informants as possible. The interviews were tape recorded and the same interview schedule was used in each case. The schedule consisted of the following five questions:

1. What do you understand by the term information literacy?

2. What do you therefore regard as the distinguishing features of an information literate person? 
3. Which programmes/projects at your institution or in your experience may qualify as projects or programmes that will enhance information literacy in students?

4. Please list what you would regard as the key characteristics of information literacy programmes?

5. What are the characteristics of an environment in which information literacy and programmes enhancing information literacy will flourish?

\section{Describing information literacy}

The first question, which asked for expressions of how information literacy is understood, generally produced responses that were highly consistent with the literature in the field. This illustrated the extent to which the participants actually were involved and grappling with issues relating to information literacy and indicated that they had been correctly identified as key informants.

Respondents readily agreed that information literacy skills were not to be narrowly defined, but that they consisted of a combination of library skills, computer skills, media skills and traditional literacy skills, functioning within a context of being able to make productive and competent use of retrieved information. One group succinctly expressed that an information literate person was one who could recognize an information need, knew where to look for information, had the necessary skills to access that information from a selection of sources, was able to evaluate the information obtained and then could use and communicate the obtained information to others: a definition highly consistent with that found in the Information literacy blueprint from Australia (Bruce, 1994).

Another group contributed the useful insight that it could be problematic to settle for too rigid a definition, as information literacy is not only highly dependent on context, but that the access tools and approaches to information are in a constant state of flux and development and should not be pegged down by fixed definitions. A need was expressed for a 'durable' definition that would remain relevant in spite of rapidly shifting contexts and technologies.

This group was particularly concerned with the information technology component of information literacy and the importance of the computer as the tool for managing information. While some members of the group seemed to imply that mastering information technology was the most significant aspect of becoming information literate, one member of the group expressed the conviction that printed tools and sources may be more appropriate in satisfying certain information needs. While this was accepted, there was support for the speaker who declared that printed books would ultimately become too expensive to be sustained and that computers will be the information tools of the future.

The groups agreed that information literacy was a lifelong process that developed throughout a student's career. It is not an attribute that only pertains to an academic elite, but a lifeenhancing skill that all students should be empowered to obtain.

\section{Information skills}

A question about the actual skills required to be an information literate person, produced a lengthy discussion in the first group, which served to enrich the research team's understanding of information literacy in the context of specifically South African academic disadvantage. It was emphasized that information literacy consisted of an 'infusion' of various different skills, many of which may be taken for granted by teachers and lecturers, but which students simply do not possess. 'Recognizing an information need', for example, includes having to know what the use or purpose of information could be. Not only are students unfamiliar with libraries and computers, they are often unaware that a whole range of other information sources also 'count' as such: newspapers, films, videos, the telephone, the yellow pages and other people.

Students have difficulty in knowing how and where to start a search for information and do not realize that it is unlikely that there would be a single source containing all the answers. Simply repackaging information to make finding it easier, was regarded with suspicion by the interviewees, as students may then rely too much on the repackaged material and never become information literate.

Reading skills were regarded as an essential component of information literacy: students should be able to decode a text meaningfully. Some find it difficult, for example, to recognize 'voices'; to know when an author is expressing an opinion, or whether someone else is being quoted. 'Reading between the lines' or understanding what is suggested rather than overtly stated, is problematic, as are the numeracy skills required for example in obtaining useful information from a graph or a chart. It was emphasized that information literacy was not a skill that could simply be taught; it was a practice, which could only be acquired by much practising.

One group suggested that the acquisition of information literacy was not a natural process, but that it was built upon in the first place the learning of the specific language and terminology of a subject field. Such subject skills, however, had to be coupled with data processing and technological skills, as the ability to access information through a variety of technological tools also formed an essential aspect of information literacy. In addition, remaining information literate after tertiary education might require new learning, the acquisition of different skills in the use of the latest electronic tools and much more effort to stay abreast of information in a specific field.

The importance of higher order cognitive skills was emphasized by two of the groups. The skill of distilling relevance, for example, is critical in view of the rapidly shifting contexts and vast amounts of information out there which students have to navigate. Thinking skills such as being able to evaluate critically, to sift, assess and source information, have to be gained by experiential learning and practice and cannot be trivialized by attempts to pin them down as single, teachable skills.

It was also noted that affective factors play a significant role in the acquisition of information literacy. Without 
confidence or motivation, or even natural curiosity, students would not be able to deal effectively with a recognized information need.

\section{Relationship between information literacy and knowl- edge production}

One group spent some time exploring the relationship between information literacy and knowledge production. It was suggested that information literacy was the ultimate aim of all tertiary education: to produce people immersed in the conceptual framework, the terminology, philosophy and methodology of a subject and who were equipped with the tools allowing them to maintain currency and to continue educating themselves in that field after leaving the educational institution. The group therefore spent some time discussing the use of the word 'literacy' and whether the discussion was suggesting that the concept 'information literacy' was so broad and all-inclusive as to be of little value in definition.

In defending the use of the term in this context, it was argued that traditional literacy did not simply concern the ability to read and write, but was crucially associated with the social practices surrounding language. Information literacy therefore included knowing how knowledge was organized and how to reproduce or generate new knowledge. Information literate people are able to write or to share; to produce new knowledge and to communicate to others the products of their active learning.

This communication or reproduction of knowledge might take place in a variety of ways. One of the groups especially emphasized that oral cultures and traditions should be recognized alongside that of the printed, written word which was in any case now being challenged by the much more ephemeral nature of the electronic text. Information literate people are able to move easily and confidently between information sources and know what to do with information, once it has been found.

\section{Contextualization of information literacy}

All the groups considered the question of the contextualization of information literacy skills: whether information literacy is a generic attribute which may be regarded as the goal of all tertiary education, or whether it is context or discipline specific. Were information literacy skills best taught as a separate course on the understanding that they were transferable skills which, once learnt, could be applied in any situation, or is it best to teach them in some coursespecific context?

Two groups noted that aspects of information literacy were not context sensitive; that the world no longer was as discipline driven as in the past and that there might well be a 'general communicative competence' that could be taught in an interdisciplinary approach. Several interviewees, however, expressed the conviction that these skills where not necessarily transferable; that the information skills required by a student in the fine arts, for example, were vastly different from those required by a student in physics or chemistry. It was recognized that all teaching of information literacy needs to address common issues such as coverage, currency and validity to impart certain generic, transferable skills, but it was also accepted that this teaching cannot successfully take place outside a specific subject area and without using the language or terminology of that subject.

After considerable discussion, both groups tended to agree that information literacy skills were best taught within the context of a specific subject. It was felt that information literacy cannot be divorced from the discourse of a subject field, as one required an understanding of the specific language and terminology associated with a subject to comprehend an information need and recognize relevant information.

The first group confirmed that while information literacy skills were best learnt and practised within a specific subject, they would be learnt even better if they were taught within a number of different subjects. It was also noted that information literacy skills might be taught more effectively when they are 'silently infused' and not openly present in the curriculum. Another group seemed to suggest that the teacher should be conscious of nurturing information literacy in learners, without necessarily making it overt.

An important aspect of the contextualization of the concept of information literacy that emerged, was the recognition of the importance of the particularly South African context. The pilot interview had provided the Research Team with the insight that students at present in the five institutions exhibited a wide diversity of backgrounds and that an effective, student-centred approach to learning would have to take into consideration the prior learning experiences that the students brought with them. Such a more flexible approach to learning will also take into consideration that a student's own experience could be a legitimate information resource.

\section{Factors that enhance information literacy}

It was recognized that a number of existing courses at the three universities and two technikons teach aspects of what may be called information literacy, even though the courses themselves might bear no evidence of that terminology. The extent to which this is done, is frequently related to money, as teachers tend to do what they regard as most necessary and feasible within the operative constraints. It was, however felt that not a great deal of explicit information literacy skills teaching was going on outside the libraries, where much of it still took place in the guise of bibliographic instruction, and in the departments of academic development, where these issues were of major concern.

Two of the groups were convinced that a paradigm shift was required before the institutions could be able to claim that they aimed to produce students who were truly information literate. Most courses at present were lecturer centred and dependent, in the traditional mould where the lecturer is regarded as the source of all the knowledge needed by the student in order to qualify. Students therefore have to become 
more dynamically engaged in their own learning and have to be actively exposed to a range of information sources appropriate for their specific disciplines. The critical, defining feature of an information literacy focus to teaching and learning, the groups thought, was a shift to a mode that was more student-centred, with the aim of producing students that were not only immersed in their subjects, but confident with using productively a variety of information tools and sources specific to those subjects. Partnerships between librarians and teachers were crucial in this regard.

Many obstacles to a paradigm shift of this nature were noted. It was emphasized that such a shift had significant budgetary implications and that a commitment to redefine an institution as a learning organization, had to be championed by the top management structure in the first place. Only involvement at this level would ensure that the resources required for the implementation of change (such as the provision of infrastructure providing all learners with access to electronic information resources) would be available. Anxiety was expressed at the rapidity with which tools and technologies were changing, while institutions were faced with increasing resource constraints and the inability to provide general access to the latest tools and technologies for both undergraduate and post-graduate students at an institution.

One of the groups was particularly concerned with obstacles from the learners themselves. Often students, especially from disadvantaged backgrounds, come to tertiary education with a dualistic world view and expect to be provided with the 'correct' answers or with specific texts. They find it very threatening to be presented with different points of view and a lecturer's expectation that they should be able to distil and defend an individual position. Such students were satisfied with and indeed demanded reading lists and course readers. They do not wish to explore the world of information by themselves, while lecturers generally provide very little assistance in an activity which they regard as a student's own responsibility.

It was agreed that successful information literacy courses at present, were those with limited but achievable objectives, which were learning-centred, integrated into specific subject courses, activity focussed and which essentially attempted to effect a transformation by empowering students to take charge of their own learning. In addition, all the groups emphasized that the acquisition of information literacy was a developmental and indeed a life-long process that cannot be taught once and for all or in a fairly brief period.

\section{Approaches to a definition}

Both the literature review and the interviews strongly suggest that it is problematic to achieve a definition of the notion of information literacy that readily lends itself to operationalization. It was however possible to identify various subconcepts and factors relating to the definition of information literacy in general and with specific reference to South Africa. These are:

\section{Prior learning experiences}

Due attention needs to be paid to the fact that students from vastly under-resourced educational systems have not been exposed to information sources and technologies that require or foster the development of information literacy. Thus learners bring differing educational experiences to teaching and learning at the tertiary level. This also implies that attention should be focussed in the linguistic competence of learners which have a bearing on their ability to access and utilize informational resources.

\section{Contextually specific teaching and learning}

Any definition of information literacy in South Africa should take into account various contextual features of the South African tertiary education system which impinge on teaching and learning. These include inter alia the fact that educational technology resources are unevenly distributed across the five institution in the Western Cape province.

\section{Affective issues}

Any definition of information literacy must incorporate the understanding that learners are able to identify when they have an information need and are confident and motivated to explore the world of information.

\section{Access skills}

Allied to motivation, information literacy presumes that learners possess the necessary skills and ability to access information from various sources. This includes the library, electronic databases and computer networks. For this to be possible, learners should possess various literacies such as computer literacy and library literacy.

\section{Use and evaluation}

Having identified and accessed appropriate and relevant sources of information, information literacy denotes a learner's ability to critically evaluate and use the information to solve problems, accomplish tasks and generate new ideas.

\section{Higher order cognitive skills}

Critical evaluation and manipulation of information implies that learners possess higher order cognitive skills which enable them to generate new ideas and contribute to knowledge production. Information literacy thus refers to a set of cognitive skills which allows learners to discriminate between information obtained from various sources and to apply the information.

\section{Student-centred learning}

Central to the definition of information literacy is the assumption that with the advent of new information technologies and the vast amounts of information that is available, it is not possible for educators to provide all the necessary information to learners. It is argued that teaching and learning should be directed towards making learners independent and 
teaching them how rather than what to learn. This implies that educators should see themselves as facilitators and guides through a process instead of sages possessing all information and knowledge.

\section{Operationalizing the definition}

The summary above captures the salient points relating to the notion of information literacy that has emerged from the basic research. Grounded in the preceding discussion, a possible operational definition of the concept which was used as the baseline to develop the research instruments, is the following:

\section{Information literacy refers to the ability of learners to access, use and evaluate information from differ- ent sources, to enhance learning, solve problems and generate new knowledge.}

This definition must be understood in the context of the following, namely that in South African tertiary education, information literacy develops when situation and affective factors which impinge upon the teaching and learning process, together with the learner's prior learning experiences, are recognized by learners and teachers alike. Information literacy is most effectively imparted in an environment which is centred around the learner rather than the teacher in a collaborative relationship which also includes other facilitators such as librarians, and specialists in computer applications and academic development. The development of information literacy is directed towards producing independent and selfdirected learners who are able to become active and responsible citizens, make informed decisions in their private and public lives and contribute to both individual and national empowerment and growth.

\section{Conclusion}

This definition in conjunction with the contextual issues as outlined above, attempts to capture the major insights that have emerged from the investigation. The critical issue that had to be addressed, was to use the above working definition to develop appropriate and relevant research instruments for the purposes of conducting the research. This process is continuing with the design of a research instrument which is aimed at producing operation indicators of information literacy based upon the definition which emerged from the preliminary research. This instrument was administered to representative samples of students on the five CALICO campuses during August and September 1996.

\section{Note}

1. This paper emerges from the work of the INFOLIT Project directed by Ms. C.M. Karelse. The authors would like to thank the project for permission to use the information and acknowledge the support received. However, the views expressed in the article are those of the authors and do not therefore reflect that of INFOLIT. Further information on the project can be obtained from the Director email: cmk@grove.uct.ac.za; Greenwich Grove, Rondebosch, Cape Town.

\section{References}

ADAMS, S. \& BAILEY, G. D. 1993. Education for the information age: is it time to trade vehicles? NASSP bulletin, May:57-63.

BEHRENS, S. 1992. Undergraduate library and information skills in a distance learning environment (DBibl thesis). Pretoria: University of South Africa. (Unpublished).

BEHRENS, S. 1993. User education at tertiary level: a review of recent literature. South African journal of library and information science, 61(13):124-130.

BEHRENS, S. 1994. A conceptual analysis and historical overview of information literacy. College \& research libraries, 55(4):309-322.

BREIVIK, P.S. 1987. Making the most of libraries. Change, 19(4):44-52.

BRUCE, C.S. 1995. Information literacy: a framework for higher education. Australian library journal, 44(3):158-170.

BRUCE, C.S. 1994 Information literacy blueprint. [Online]. Griffith University: Division of Information Services. Available:http:// www.gu.edu.au/gwis/ins/infolit/blueprnt.htm.

FORD, B.J. 1995. Information literacy as a barrier. IFLA journal, 21:99-101.

KANTER, J. 1995. Computer-information literacy for senior management. Information strategy: the executives journal, Spring:612.

LENNOX, M. F. \& WALKER, M. L. 1993. Information literacy in the educational process. The educational forum, 57(Spring):312324.

MAKHUBELA, L. \& KOEN, Z. 1995. Another angle on access: information literacy and student learning. Academic development, 1(1):13-19.

MARAIS, J.J. 1994. Information literacy and quality of life. Free State libraries, July/Sept:13-19.

MCCLURE, C. R. 1994. Network literacy: a role for libraries. Information technology and libraries, 13(2):115-125.

NATIONAL EDUCATION POLICY INVESTIGATION. 1993. Adult education. Cape Town: Oxford University Press/National Educating Co-ordinating Committee.

RADER, H.B. 1994. Library orientation and instruction -1992. Reference services review, 22(2):79-95.

RADER, H. B. 1995. Information literacy and the undergraduate curriculum. Library trends, 44(2):270-278. 